\title{
The New Leadership Model of University Management for Innovation and Entrepreneurship
}

Gamze SART ${ }^{*}$

\section{Suggested Citation:}

Sart, G. (2014). The new leadership model of university management for innovation and entrepreneurship. Eurasian Journal of Educational Research. 57, 73-90. http:/ /dx.doi.org/10.14689/ejer.2014.57.6

\begin{abstract}
Problem Statement: Today's ever-changing educational environment has created a need for new leadership styles that encourage positive change and improvement. In Turkish universities, the most commonly used leadership models are the classic and/or traditional ones, which lead to stagnation in innovation and entrepreneurship. Only a limited number of universities are actively engaged in innovative research activities and achieve success in terms of entrepreneurship and cooperative work with industry. A broad effort is needed to improve cooperation and encourage leadership development.

Purpose of Study: This paper attempts to show and critically analyze the role of leadership models of university management in creating a learning environment for innovation and entrepreneurship.

Methods: Semi-structured interviews were conducted with 42 different faculty members and 12 graduate students over a period of three months at three different universities in Istanbul. Interviews were centered on 6 core research questions. Interpretative Phenomenological Analysis (IPA) was used to analyze the interview outcomes. The data were analyzed using the Atlas.ti 7 software kit.
\end{abstract}

Findings and Results: A large percentage of the participants, $78 \%$, mentioned that participatory democracy is an important new leadership model that can empower innovation and entrepreneurship. Most respondents, $80 \%$, also identified the important role of intensive collaboration with industry managers. In the transformation of the university, a significant percentage of the participants, $69 \%$, agreed that experts should be frequently consulted and their views taken into

* Dr. İstanbul University, Faculty of Education, E-mail: gamzegazi@gmail.com 
consideration. Slightly more than half of the participants, $54 \%$, said that their university could do more to encourage innovation and innovative ideas from students and faculty members; out of the respondents who expressed this idea, the majority, $86 \%$, said that new leadership and management styles would be critical in promoting this change.

Conclusions and Recommendations: As the current study shows, universities that apply new leadership styles create an environment more conducive to fostering entrepreneurship and innovation. Consistent with previous research, the leadership model of university management plays a vital role in universities' readiness to accept innovative and entrepreneurial changes. Universities should adopt new leadership styles instead of using conservative and traditional leadership models that discourage innovation and entrepreneurship. Generally speaking, democratic leadership models are more effective at fostering open innovation. In the new management framework, leaders can create new environments and spaces, such as technology transfer offices, to collaborate with industry.

Keywords: New Leadership Model, University Management, Innovation, Entrepreneurship

\section{Introduction}

There has been a problem with regard to leadership and entrepreneurship in Turkish universities. The Scientific and Technological Research Council of Turkey (TÜBITTAK) has only recently decided to rank Turkish universities in terms of entrepreneurship and innovation. The following table provides a clear picture of the current situation.

\section{Table 1}

Entrepreneurial and Innovative University Index, 2014 Ranking

\begin{tabular}{|c|c|c|c|c|c|c|c|}
\hline Rank & University & Total & $\begin{array}{l}\text { Scienti } \\
\text { fic and } \\
\text { techno } \\
\text { logical } \\
\text { resear } \\
\text { ch } \\
\text { compe } \\
\text { tence }\end{array}$ & $\begin{array}{l}\text { Intelle } \\
\text { ctual } \\
\text { proper } \\
\text { ty } \\
\text { pool }\end{array}$ & $\begin{array}{l}\text { Coopera } \\
\text { tion and } \\
\text { interacti } \\
\text { on }\end{array}$ & $\begin{array}{l}\text { Entrepre } \\
\text { neurship } \\
\text { and } \\
\text { innovati } \\
\text { on } \\
\text { culture }\end{array}$ & $\begin{array}{l}\text { Economic } \\
\text { contributi } \\
\text { on and } \\
\text { commerci } \\
\text { alization }\end{array}$ \\
\hline 1 & $\begin{array}{l}\text { Orta Doğu } \\
\text { Teknik } \\
\text { University }\end{array}$ & 83.09 & 19.6 & 8.7 & 22.4 & 13.8 & 18.8 \\
\hline 2 & $\begin{array}{l}\text { Sabanc1 } \\
\text { University }\end{array}$ & 81.44 & 19.5 & 6.2 & 25.0 & 12.5 & 18.3 \\
\hline
\end{tabular}


Table 1 Continued...

\begin{tabular}{|c|c|c|c|c|c|c|c|}
\hline 3 & $\begin{array}{l}\text { Boğaziçi } \\
\text { University }\end{array}$ & 76.34 & 18.5 & 5.5 & 24.1 & 10.0 & 18.2 \\
\hline 4 & $\begin{array}{l}\text { Ihsan } \\
\text { Doğramacı } \\
\text { Bilkent } \\
\text { University }\end{array}$ & 74.96 & 19.1 & 5.2 & 22.4 & 12.7 & 15.6 \\
\hline 5 & $\begin{array}{l}\text { Koç } \\
\text { University }\end{array}$ & 73.59 & 16.0 & 9.4 & 24.9 & 11.3 & 12.0 \\
\hline ... & $\begin{array}{l}\ldots \\
\text { Firat } \\
\text { University }\end{array}$ & $\begin{array}{l}\ldots \\
29.56\end{array}$ & $\begin{array}{l}\ldots \\
8.7\end{array}$ & $\begin{array}{l}\ldots \\
1.2\end{array}$ & $\begin{array}{l}\ldots \\
4.1\end{array}$ & $\begin{array}{l}\ldots \\
9.8\end{array}$ & $\begin{array}{l}\ldots \\
5.8\end{array}$ \\
\hline 47 & $\begin{array}{l}\text { Kadir Has } \\
\text { University }\end{array}$ & 29.19 & 10.1 & 0.0 & 13.9 & 0.3 & 4.9 \\
\hline 48 & $\begin{array}{l}\text { Pamukkale } \\
\text { University }\end{array}$ & 28.84 & 7.3 & 3.5 & 10.0 & 2.4 & 5.6 \\
\hline 49 & $\begin{array}{l}\text { Niğde } \\
\text { University }\end{array}$ & 28.25 & 7.8 & 2.5 & 12.3 & 1.5 & 4.2 \\
\hline 50 & $\begin{array}{l}\text { Ondokuz } \\
\text { Mayis } \\
\text { University }\end{array}$ & 28.22 & 7.9 & 2.4 & 10.8 & 7.2 & 0.0 \\
\hline
\end{tabular}

As seen from the table, only a few universities are more or less successful in terms of innovation and entrepreneurship. To make matters worse, only 50 of approximately 200 Turkish universities have been included in this ranking. Therefore, one can easily identify two major problems:

1. Even among the 50 universities that are ranked, there is a huge gap between the first and the last (83.09 versus 28.22);

2. Approximately 150 universities are not even included on the list.

This paper is an attempt to take a critical look at these issues and propose a solution that might offer a significant contribution to the field.

The education given at a university has a direct effect on industry and technology, as these are where educational know-how can be applied to influence the economic development of a country (Ozturk, 2001). This important role of the university is affected positively or negatively by the leadership model of that university's management. For this reason, the leadership model of a university is crucial in promoting innovation and entrepreneurship. Universities must predict the need for change and implement change proactively. Different leadership models play a critical role in guiding such change (Cross, 2012). There are many leadership styles that are increasing in importance not only in universities but also in every area of professional life. As the importance of these styles grows, several questions become 
critical for society: "Are the new leadership models suitable for all areas of life or not?" and/or "Are traditional leadership models still the most effective?" However, 'leadership' should first be defined as a concept before considering the question of whether modern leadership styles or more traditional leadership models are better suited for producing university management that promotes innovation and entrepreneurship.

Before analyzing a university management leadership model's effect on innovation and entrepreneurship, it is important to create a perception of leadership. A leader is a person who organizes and holds responsibility over a certain, defined group of people. However, this position is not all that is required to be a leader. A leader must have a plethora of other qualities according to various theories and models. First of all, there is more than one definition of leadership. Different leadership styles incorporate different definitions of leadership, which in turn shape different understandings of managerial roles. There are three managerial roles at senior positions: manager, coach and leader. Thus, leadership is one of these three roles. All senior positions must include coaching in addition to leadership because coaching develops the team and creates the plan (Hays, 2012). Although there are many different definitions of leadership, the Oxford English Dictionary defines leadership as "the dignity, office, or position of a leader, esp. of a political party", "the ability to lead", "the position of a group of people leading or influencing others within a given context", and "the action or influence necessary for the direction or organization of effort in a group undertaking" (leadership, 2014). However, these dictionary definitions are not sufficient to define leadership. Chemers $(1997 ; 2000)$ defines leadership as a process of social influence in which one person is willing to accept support and help from others to reach a mutually beneficial goal. Classic definitions of leadership, therefore, are reminiscent of "an all-powerful tough-guy of comic book hero proportions" or "a seemingly omniscient individual blessed with unusual foresight" (Smolenyak \& Majumdar, 1992, p. 28). These perceptions were valid for hundreds or even thousands of years throughout human history, but today's changing environment changes leadership, as well. Grint (2004, p. 6) indicates four problems with traditional leadership. The first is a 'process' problem: "a lack of agreement on whether leadership is acquired from the personal qualities (i.e., traits) of the leader, or whether a leader induces followership through what s/he does (i.e., a social process)." The second problem involves "position", referring to a dilemma where it is unknown whether the leader is "in charge" or is merely "in front" (i.e., with informal influence). The third problem is 'philosophy'. As Grint describes, this problem is manifested in the question: "Does the leader exert an intentional influence on the behavior of followers, or are their manifest actions determined by context or even attributed retrospectively?" The fourth and final difficulty is 'purity', which is related to whether leadership is embodied in groups or is a purely individual phenomenon.

It can be seen that leadership is a collective notion that touches upon many important social, organizational, and personal processes. These processes include influence and inspiration to work towards group goals, not through coercion but 
through personal motivation. Which definition to accept is a matter of choice for the organization and/or the leader, informed by his/her own tendencies, beliefs and the organizational situation but with "an awareness of the underlying assumptions and implications of his/her particular approach" (Bolden, 2004, p. 15). In addition to these definitions of leadership, leadership styles also change from one institution to another. Whereas some institutions require change, others do not need it at all. The needs of an institution affect the leadership role of the senior manager (Hays, 2012). According to Hays (2012, p. 346), there are three important attributes of a good leader. First, a leader must be a good communicator. All staff and all people connected to the organization must be clearly informed of the strategy and its implementation. Hays mentions that "certainty is crucial for confidence, and that a second attribute of a good leader is having a strong awareness of self and other team members, strengths and weaknesses, personality and personal interests. This attribute is essential for optimal team performance achievement." Hays (2012) also indicates that these leadership characteristics can create a championship team without any individual champions. The third and last attribute of any leader is the ability to delegate decision-making to the team. When the organizational structure is flat, more people contribute to the decision-making process. In other words, the larger the organization, the more important this attribute becomes (Hays, 2012).

To clarify this paper's topic, new leadership styles need to be considered and implemented. However, just as in the case of leadership, leadership styles also have different definitions. According to Nanjundeswaraswamy and Swamy (2014) "today's organizations demand effective leaders who understand the complexities of the rapidly changing global environment" (2014, p. 58). If employees have good relationships with their leader and the work that must be done is well structured, the productivity from the leadership is usually high. There are many different leadership styles in the literature. Examples of these leadership models include transformational leadership, transactional leadership, moral leadership, charismatic leadership, adaptive leadership, autocratic leadership, authoritative leadership, laissez-faire leadership, and spiritual leadership (Virkus, 2009). According to Bass and Steidlmeier, there are "two distinct but interrelated ideal types of leadership: transactional and transformational" (1999, p. 187). Transactional leadership involves contingent reinforcement. Bass and Steidlmeier add that in this model, "leaders motivate the followers by their praise, promises, and rewards or correct them by negative feedback, threats, reproof, or disciplinary actions. The leaders react to whether followers carry out what the leaders and followers have 'transacted' to do." Within the model of contingent rewards, "behavior leaders either make assignments or consult with followers about what is to be done in exchange for implicit or explicit rewards and the desired allocation of resources" (Bass \& Steidlmeier, 1999, p. 195). Transformational leadership consists of four components. These are "charisma or idealized influence (attributed or behavioral), inspirational motivation, intellectual stimulation, and individualized consideration" (Givens, 2008, p. 20). Subjects "identify with the charismatic leaders' aspirations" and tend to imitate these leaders in various ways. Leaders' "charisma or idealized influence is envisioning, if it is transformational" (Mills, 2007, p. 13). 
The next step is to analyze the leadership models of universities. Previous research studies have offered two criticisms of university leadership. The first concern is that there has been insufficient development of robust styles of professional management and the second is that conventional thinking and behavior are unchallenged, if not encouraged, because most university leaders have advanced their careers within the system (Scott, 2011). Studies demonstrate that, in particular, transformational leadership produces desirable outcomes for the universities' organizational effectiveness (Pounder, 2001). However, Scott (2011) also mentions that classic university leadership styles can also have advantages; specifically, most senior managers remain firmly embedded in the academic culture. That is, nearly all of the senior managers within this model still regard themselves as academics, albeit inactive ones, as well as managers. This identification gives them a crucial advantage in their internal leadership role. Scott nonetheless suggests that universities may need to develop new leadership models that can provide increased intellectual resources to students and faculty members so that they can better make sense of the complex economic, political, social, and cultural landscape of the twenty-first century world. Highly personalized, informal and widely distributed leadership styles may offer such a model, and a reversion to older models of "collegial" government may offer another. However, neither of these two models is perfect. Whereas the first model may be difficult to adapt to public institutions, the second one is encrusted with memories of irresponsibility and inertia. Nonetheless, either of these models may provide a starting point for the big organization corporate model that is slowly but surely becoming established as the norm in universities (Scott, 2011).

Leadership and entrepreneurship are closely connected in a number of ways. "Entrepreneurship is an expression of efficacy in change being possible whether for profit or not for profit. Especially among recent college graduates and college students, leadership is incrementally being carried out in the form of entrepreneurship" (Ives, 2011, p. 85). Thus, "What is entrepreneurship?" and "What is innovation?" are two questions that must be answered. According to the MerriamWebster Dictionary, an entrepreneur is "a person who starts a business and is willing to risk loss in order to make money", and innovation is "the introduction of something new" (entrepreneur, 2014; innovation, 2014). In universities today, many students are interested in "being entrepreneurial leaders who affect change in the marketplace and society through creating new for-profit and nonprofit entrepreneurial ventures, instead of serving as more traditional leaders who work to affect change from within existing organizations" (Ives, 2011, p. 87).

In a university whose management operates under a traditional leadership style, improvements in the area of innovation and entrepreneurship will often not be supported. However, research shows that universities that are open to new leadership styles are also more open to innovation. Although there has been intense academic interest in the leadership literature, the studies that examine leadership's relationship with innovation and entrepreneurship in educational settings are limited. The current study aims to extend previous works by analyzing the effect of new leadership styles of university management on creating a learning environment 
for innovation and entrepreneurship. Another important and distinguishing factor of this paper is its use of Interpretative Phenomenological Analysis (IPA) as an analysis method to understand participants' perception of the term 'effective leadership models in universities.' With this detailed analysis, the study aims to provide several useful directions for universities and planners of leadership development programs.

In this context, the purpose of this paper is to establish the role of the new leadership and management styles in helping to promote change and encourage innovation and innovative ideas from students and faculty members. Generally speaking, this paper endeavors to answer the following primary questions: "What type of leadership model is needed to encourage innovation?" and "What is required of university management to promote entrepreneurship in universities and increase industry-university collaboration?"

\section{Methods}

Research Design:

To collect the opinions of faculty members and graduate students, semistructured interviews were conducted in three different universities in Istanbul. The interviews were centered on 6 core research questions.

Research Sample

Cluster sampling was utilized in the study. One private and two state universities of Istanbul were selected as major clusters. Within these, further clustering was performed in terms of majors: subjects were randomly selected from three different faculties (Engineering, Medicine and Social Sciences) at these three universities. Faculty members and graduate students are usually involved in innovative research in universities; hence, the sample of the current study consisted of two sub-groups: 42 faculty members and 12 graduate students. The age range was $24-28$ for graduate students and 36-55 for faculty members. The distribution of faculty titles with regard to gender and department is given in detail in the following table.

Table 2

of Sample Subgroups with Respect to Faculty and Gender

\begin{tabular}{ccccc}
\hline & & Engineering & Social Sciences & Medicine \\
\hline \multirow{2}{*}{ Faculty members } & F & 8 & 9 & 6 \\
& M & 6 & 8 & 5 \\
Graduate Students & F & 2 & 2 & 2 \\
& M & 2 & 2 & 2 \\
\hline
\end{tabular}




\section{Research Instrument and Procedure}

The author conducted a comprehensive literature review while developing the research question. The author was the researcher and the interviewer during the study process, and she generated core questions based on the literature review. Furthermore, five different experts in the field were asked to review the questions to reach a higher level of content validity for the study. Finally, after approval was received from the Ethics Committee, the study was conducted during the spring semester of the 2013/2014 academic year. The researcher visited the selected universities to conduct the interviews. Clear instructions about the procedure and the purpose of the study were provided to the participants. Informed consent, confidentiality and voluntary participation were also ensured. The average interview time was 2 hours. Interviews were conducted face to face, and a voice recorder was used with the permission of the participants.

The 6 core questions were as follows: (1) What type of leadership models do you recommend to increase innovation and entrepreneurship in universities? (2) In your opinion, what is required in the new leadership model of university management? (3) What is required to increase industry-university collaboration? (4) What should be changed first to provide this type of leadership model of university management? (5) What is the role of university management in effective industry-university collaboration? (6) How can new leadership models be applied in universities?

\section{Data Analysis}

Atlas.ti 7 software was used for the data analysis. Forty-two faculty members and 12 graduate students were coded as F1, F2, F3... and S1, S2, S3 ... etc., and descriptive information was obtained. First, the author transcribed all interviews. After the transcription, the written documents were compared with the audio records for further control. Participants' responses were examined in detail and divided into different categories, arranged by content. Interpretative Phenomenological Analysis (IPA) was used to explore how subjects made sense of their experiences and to identify the significance of those experiences to the subjects themselves. Together with IPA, semi-structured interviews are usually used as the best method for collecting data (Chapman and Smith, 2002). In this process, the transcripts were subjected to a case-by-case in-depth analysis. Each transcript was examined repeatedly by taking notes, including interpretations. Afterward, these comments were transferred into themes and connected until coherent thematic integrity was achieved for each participant. After the case-by-case analysis was completed, the themes were connected across participants, and superordinate themes were grouped: (A) "Scientific and technological research competence," (B) "Intellectual property pool," (C) "Cooperation and interaction," (D) "Entrepreneurship and innovation culture," and (E) "Economic contribution and commercialization." Finally, the analysis was translated into a narrative account to provide a reportable format for the paper. 


\section{Results}

Generally speaking, the results obtained after the aforementioned analysis turned out as expected: a great need for new leadership models was felt and clearly witnessed.

A large percent of the participants, 78\% (42 subjects out of 54 ), mentioned that participatory democracy should be an important component of a new leadership model to empower innovation and entrepreneurship in universities. Regarding the new leadership management, most of the respondents, $80 \%$ (43 subjects out of 54 ), stressed the role of more intensive collaboration with members of industry who play an important role in management. Concerning the transformation of the university, a significant percentage of the participants, $69 \%$ (37 subjects out of 54), agreed that the views of experts should be taken into consideration. Nearly half of the participants, $54 \%$ (29 subjects out of 54), said that their university could do more to encourage innovation and innovative ideas from faculty members and students. A large majority of the respondents who expressed this idea, $86 \%$ ( 25 subjects out of 29 ), also stated that new leadership and management styles would be critical in helping to promote this change.

When participants were asked about their recommendations for leadership models that could increase innovation and entrepreneurship in universities, the three keywords most frequently articulated by the participants in different forms were 'participatory democracy', 'participatory leadership' and 'democratic leadership'. Participants mentioned the importance of respect and engagement in university management to achieving real development and growth. An absolute majority of participants agreed that the universities at which they study or work at should possess more democratic and more effective models of leadership. Because educational leadership has not yet been sufficiently conceptualized by the academic community, the variance for the codes derived during interviews from the participants' answers to the first question was high. However, there was a remarkably high consistency in the statements in terms of democratic practices to be applied by the university management. Participants expressed their belief that the most effective and productive learning environments could be provided via better internal and external contributions. They wanted to take a more participatory role in the decision making process and also sought to involve other people in the process. For those participants who did not directly use the word 'participatory democracy' in the university management leadership model, 22\% (12 out of 54 participants), there was again a significant emphasis on the influence of others on the leader's decision. However, there was a hierarchy between answers in terms of how exactly how participatory the leadership style should be. There was only 1 participant who supported the view that leaders should make autocratic decisions. Four participants said that a leader should listen to feedback and talk with others but should ultimately make the final decision by him- or herself. Four participants favored a model in which a team processes decisions, yet the final decision still belongs to the leader. Three participants mentioned a joint decision-making style carried out by a 
team. This range of responses indicates that although some participants did not use the most common keywords at all, they nonetheless were thinking of the same or closely related characteristics of participatory democracy in the university management leadership model.

In the second question, participants were asked their opinion concerning the requirements for a new leadership model of university management. The most frequently appearing keyword was 'intensive collaboration'. Both faculty members and graduate students mentioned the shared responsibility of the university management in action for faculty members, students, managers, other stakeholders, government, and even the public. A large percentage of the participants mentioned the link between academia and industry in promoting innovation and entrepreneurship. One of the participants insistently emphasized the advantages of this type of collaboration, saying, "University-industry collaboration is a must in the new era. It enhances the university's research mission and advances its position as a leading source of innovation. It also provides a public service, benefits the economy by attracting investment, creates jobs and enhances the quality of life. Academicians who do not see this will always be behind the times."

In the third question, participants were asked, "What is required to increase university and industry collaboration?" Participants mentioned the role of industry managers in university management leadership. Some participants gave examples from Turkey, where many company owners have built private (foundation) universities, thereby empowering intense collaboration. Faculty members from private universities mentioned corporate and institutional partnerships. One participant said, "This is an excellent opportunity for the industry to have an innovative partner, to access good research, different pools of knowledge, talented future employees and to save costs on Research and Development." In general, participants held the view that companies must actively embrace universities. In their opinion, the differences between industry and academia can be transformed into a significant advantage through collaboration.

"What should be changed first to provide this type of leadership model of university management?" was the fourth question. As can be inferred from the narratives, the communication between industry and academic teams is a lower level than expected. The process is generally hampered and slowed by bureaucracy. For this question, the keywords derived from a large percentage of the participants' answers were 'communication' and 'sharing ideas'. Subjects stress the importance of face-to-face encounters in which both university management and stakeholders can enthusiastically pass along their ideas. 'Networking' is yet another keyword that is frequently found in the answers to the fourth question. Between universities and the business community, networking is a critical component of an efficient innovation. Some of the participants gave several national and international examples of established networking tools that create links between universities, business and research technology organizations. They thought that these mechanisms should be reviewed and updated as innovations that can change communication capabilities and expectations. According to the data analysis, the participants frequently articulated responses within many subcategories of the superordinate theme 
'communication'. Integrated as meaningful units, they appear as the following: 'common understanding of the objectives', 'constant contact in both directions', and 'sharing operational and strategic decisions'. Participants also evaluated open communication as a part of problem solving. One faculty member gave an example: "Universities cannot deliver all the services that industry desires. It is natural because the resources are scarce and sometimes the expectations do not match the reality. It can only be solved through clear and open communication between the principals at an executive level. It is essential that this be done with the mutual respect of the needs and constraints of the other party. In order to achieve this for industry-university collaboration, transparency of the responsibility at an executive level is a prior necessity."

Participants were asked about the role of university management in effective industry-university collaboration. The analysis of this question revealed that universities should adopt collaboration and transform as quickly as possible. To clarify this point, the industrial transformation of universities aims to encourage a larger number of collaborative Research and Development projects that can address challenging issues faced by industry today through innovative research. The most frequent keywords related to the expected goals from transforming university management presented a coherent unity for this question. Final statements obtained from the data analysis were 'developing an innovative mindset for students and faculty members' and 'adopting more collaborative and cross-disciplinary problem solving methods'. Faculty members said that they were not always in full agreement with regards to innovative collaboration decisions. This problem appears to be one of the most prominent of those hindering the transformation process. The majority of participants, $87 \%$, agreed that the focus of new leadership models of university management should be on promoting this change.

Lastly, participants evaluated how new leadership models can be applied in universities. The most frequently appearing keyword was 'experts'. According to the narratives derived from the interviews, expertise in the field is required to lead this transformation process. In terms of ongoing collaboration, universities generally operate within a framework of multiple partnerships that is hard to manage. The need for experts simultaneously implies the engagement of university leaders in the transformation. Fostering leadership performance and exploring how to build leadership and management skills and effect positive institutional change are essential in terms of widening the networks of leaders in the business world, academia, and other segments of society. At this point, innovation depends on the ability of university and industry experts to work together across a number of disciplines. Due to the flexible frame of the semi-structured interview method, this question also reveals the views of faculty members on another topic, i.e., the promotion of a multidisciplinary approach to research and learning to pave the way for partnerships between industry researchers and academicians based on multidisciplinary research. Through these partnerships, universities and industry can pursue solutions to complex and systemic problems that require cross-disciplinary expertise. 


\section{Discussion and Conclusions}

The goal of this paper was to discuss whether university management who use new leadership styles are more open to innovation and entrepreneurship. Findings confirmed the view that new leadership styles are more conducive for making improvements. New leadership models promote positive change among people within the university and even beyond the institutional level.

However, as signified by Simsek (2013), this change as well as new theories and concepts may not be easy to apply since new liberal ideas, even though very instrumental in promoting change in industry, have so far had a relatively weak influence on education system. On the other hand, a profound and somewhat revolutionary change of university leadership has been needed, and the importance of promoting this change has been growing.

Transformational leadership also has a great impact on the higher education itself in terms of learning and teaching (Quinlani, 2014). This aspect usually skips the attention of the researchers even though it is of vital significance since the transformational leadership is directly linked to a holistic student development and naturally leads to closer ties with markets. Even though the major constituents of such leadership are arguable, mainstream trend in this area of educational research shows that transformational leadership in its essence is very close to the idea of comprehensive collaboration of industry and universities.

According to many pieces of academic literature on leadership, a key aspect of many transformational leaders is that they are oriented towards the future, not the past. However, striving to determine and implement the desired future direction of an organization is essentially an ambiguous and uncertain undertaking (Simsek, 2013). Therefore, it is also fundamentally a risky venture, and as a result, transformational leaders are the most effective and work best in more chaotic environments. This is contrasted with transactional leaders, who best function in calm and stable periods of an organization where there are clearly defined and commonly agreed-on standards and rules. However, many would agree that the field of higher education is not in such condition now.

As was shown before, since most of the university staff members have reached top positions within the boundaries of the present academic environment (Scott, 2011), challenging this conventional framework becomes difficult. It may demand serious reconsideration of the basic principles and rules established for the area long ago. Active envolvement of the experienced academicians, despite the fact that they may tend to stick to the old framework, is absolutely necessary, as many of them are experienced leaders with valuable insight to give. This was also indirectly confirmed by the participants of this study, as they mentioned listening to experts as one of the major factors necessary to promote change.

Taking the aforementioned arguments into consideration, consistent with the literature review, the current study results show several critical points that cannot be overlooked. They can be underlined as follows: 
First, as a major component for empowering innovation and entrepreneurship within higher education, participatory democracy was on the top of the list for creating a successful future leadership model. Achieving a democratic environment at an organizational level may positively affect leadership development by expanding awareness of the primary goals and contributions expected of the organization.

Second, new models of leadership management have no future without a thoroughgoing collaboration with industry management members. With respect to this finding, as a supportive argument, a strong need for qualified experts in the area was emphasized by the participants of the study; thus, expert opinion should play a major role in the process of the higher education transformation. This may have farreaching consequences for the higher education at large, leading to re-shaping or even forming absolutely new entities and branches of management mentorship within universities. Possible future prospects of such innovations have already inspired the creation of annual Entrepreneurial University Leadership Programs and similar projects (Gibb, Haskins, and Robertson, 2013).

Third, positive and constructive changes in terms of promoting innovation within higher education cannot be achieved without a significant increase in motivation. Participants said that universities should encourage innovation and innovative ideas from students and faculty members. They emphasized the role of new leadership and management styles in helping to promote this change. The same values and goals may have a better chance of becoming embedded when they are signaled implicitly from the top, which can motivate the underlying layers of management to react in a creative way. For the universities, executive officers and senior teams can assume an important role by promoting organizational culture in a positive way in terms of innovation and entrepreneurship at their universities.

Some of the narratives have implied that there is a rather unusually high demand not only for new leadership models but new leaders as well. Thus, not only has this paper showed that universities need new leadership to strengthen their ties with real sectors of economy, but it has also indirectly proven that the demand for sustainable entrepreneurs, people who have the capacity to facilitate development, has also been growing (Lans, Blok, and Wesselink, 2014). Such disciplines like entrepreneurship education and education for sustainability must be integrated in order to achieve a stable and constantly developing framework for sustainable entrepreneurship. Such approach can be very instrumental in fostering entrepreneurial spirit in the higher education.

More generally speaking, narratives from the research participants expressed how they perceived effective leadership in universities and also emphasized the important role they attributed to intensive collaboration with members of industry, particularly those with important management positions. It is important to gather relevant information that affects strategy and operations. Leaders should listen to staff and external stakeholders. Finally, all participants of the study agreed that it 
might be quite a struggle to remain relevant and continuously improve and move in a positive direction towards innovation in higher education institutions.

One of the areas that can be suggested with regard to the continuation of the present research is the gender issue within the leadership. As Michael states (2013), women tend to exhibit a predominantly transformational type of leadership in higher education. They usually take other paths and develop highly flexible forms of leadership that can be worth of studying as a separate phenomenon or in connection with the issues discussed in the current study.

As a limitation of this study, its relatively small sample of faculty members and students can be mentioned. Therefore, it is recommended that future studies be conducted that target larger samples from different regions of Turkey, in order to draw a better picture of leadership issues in other parts of the country. Gathering data from a larger research sample and gaining insight on particular challenges that leaders face within the university environment can provide further guidance for leadership development in universities.

\section{References}

Bass, B. M. \& Steidlmeier, P. (1999). Ethics, character, and authentic transformational leadership behaviour. Leadership Quarterly, 10 (2), 181-217.

Bolden, R. (2004). What is leadership? University of Exeter.

Chapman, E. \& Smith, JA. (2002). Interpretative phenomenological analysis and the new genetics. Journal of Health Psychology, 7, 125-130.

Chemers, M. M. (1997). An integrative theory of leadership. Lawrence Erlbaum Associates.

Chemers, M. M. (2000). Leadership research and theory: A functional integration. Group Dynamics: Theory, Research, and Practice, 4 (1), 27-43.

Cross, S. E. (2012). A leadership model for the research university. $3^{\text {rd }}$ International Conference on Leadership, Technology and Innovation Management. Atlanta, GA: Elsevier.

Entrepreneur, n. (2014). Merriam-Webster dictionary. Retrieved May 31, 2014, from Merriam-Webster Dictionary:

http://www.merriam-webster.com/dictionary/entrepreneur

Gibb, A., Haskins, G., \& Robertson, I. (2013). Leading the entrepreneurial university: Meeting the entrepreneurial development needs of higher education institutions. In Universities in Change (pp. 9-45). Springer New York.

Givens, R. J. (2008). Transformational leadership: The impact on organizational and personal outcomes. Emerging Leadership Journeys, 1, 4-24.

Grint, K. (2004). What is leadership? From hydra to hybrid [Working paper]. Saïd Business School and Templeton College, Oxford University. 
Hays, R. (2012). Leadership. Blackwell Publishing Ltd, 345-347.

Innovation, n. (2014). Merriam-Webster dictionary. Retrieved May 31, 2014, from Merriam-Webster Dictionary: from

http://www.merriam-webster.com/dictionary/innovation

Ives, A. (2011). Entrepreneurship education as a new model for leadership education. Journal of Leadership Studies, 5 (2), 85-88.

Lans, T., Blok, V., \& Wesselink, R. (2014). Learning apart and together: towards an integrated competence framework for sustainable entrepreneurship in higher education. Journal of Cleaner Production, 62, 37-47.

Leadership, n. (2014, March). OED online. Retrieved May 29, 2014, from Oxford University Press:

http:/ / www.oed.com/view/Entry/106604?redirectedFrom=leadership\&

Lewis-Beck, M. S., Bryman, A. E. \& Liao, T. F. F. (2003). The sage encyclopedia of social science research methods. Sage Publications.

Michael, R. (2013). Women in leadership in higher education: Leadership styles and the (Doctoral dissertation, TREVECCA NAZARENE UNIVERSITY).

Mills, G. E. (2007). Transformational leadership and employee retention: An exploratory investigation of the four characteristics. (Unpublished Degree of Doctor in Philosophy). Capella University, U.S.

Nanjundeswaraswamy, T. S. \& Swamy, D. R. (2014). Leadership styles. Advances In Management, 7 (2), 57-62.

Ozturk, I. (2001). The role of education in economic development: A theoretical perspective. Journal of Rural Development and Administration, 33, 39-47.

Pounder, J. S. (2001). "New leadership" and university organisational effectiveness: Exploring the relationship. Leadership E Organization Development Journal, 22, $281-290$.

Quinlan, K. M. (2014). Leadership of teaching for student learning in higher education: what is needed?. Higher Education Research \& Development, 33(1), $32-45$.

Scott, P. (2011). Leadership in universities. The International Journal of Leadership in Public Services, 7 (3), 229-234.

Simsek, H. S. (2013). Transformational leadership in educational context: a fantasy of education scholars (Selected Keynotes). Eurasian Journal of Educational Research, 51, 1-6.

Smolenyak, M. \& Majumdar, A. (1992). What is leadership? The Journal for Quality and Participation, 15 (4), 28. 
Stehman, S. V. (1997). Estimating standard errors of accuracy assessment statistics under cluster sampling. Remote Sensing of Environment, 60 (3), 258-269.

Virkus, S. (2009). Leadership models/approaches. Retrieved from Leadership Models:

http://www.tlu.ee/ sirvir/Leadership/Leadership percent200M

Models/leadership_modelsapproaches.html

\title{
Üniversite İnovasyon ve Girişimcilik Yönetimi Yeni Liderlik Modeli
}

\author{
Atıf: \\ Sart, G. (2014). The new leadership model of university management for innovation \\ and entrepreneurship. Eurasian Journal of Educational Research. 57, 73-90. \\ http://dx.doi.org/10.14689/ejer.2014.57.6
}

\section{Özet}

Problem Durumu: Günümüzün sürekli değişen koşulları, liderlik kavramını da değiştirmiş ve yeni liderlik modellerinin adapte edilmesi ihtiyacını doğurmuştur. Teknolojideki gelişmeler eğitim öğretim alanında olumlu değişim ve gelişmeler sağlamış fakat inovasyon ve girişimcilik konusunda açık olan üniversiteler bundan faydalanırken, Türkiye'nin genelinde görülen geleneksel liderlik modellerinin sürdürüldüğü okullar çağa ayak uydurmaktan uzak kalmışlardır.

Araştırmanın Amacı: Bu makalede, üniversite yönetimi liderlik modelinin ileri teknoloji, yenilikçi ürün ve hizmetlere artan talepten etkilenen inovasyon ve girişimcilik ortamlarının yaratılmasındaki etkisini tartışmak amaçlanmıştır.

Araştırmanın Yöntemi: Bu çalışma, yenilik ve girişimciliğin önemli ölçüde geliştiği üniversitelerdeki liderlik modellerini eleştirel bir şekilde sorgulamaktadır. çalışmanın amacına yönelik olarak, üniversite yenilik ve girişimcilik yönetimi yeni liderlik modeli, oldukça rekabetçi bu küresel ekonomilerdeki yeni rollerini iyice anlamak için açık bir şekilde araştırılmıştır. Çalışmada, üç aylık bir süre boyunca 42 farklı öğretim üyesi ve 12 yüksek lisans öğrencisi yarı yapılı bir şekilde görüşmeler düzenlenmiştir. Katılımcılar 19 erkek 23 kadın öğretim üyesi; 6 erkek 6 kadın yüksek lisans öğrencisi olmak üzere 3 fakrlı departmandan gelmektedir (Tıp Fakültesi, Mühendislik Fakültesi ve Sosyal Bilimler Fakültesi). Öğretim üyelerinin büyük çoğunluğunu profesörler oluşturmaktadır. Öğrenciler için yaş aralığı 24-28 iken öğretim üyeleri için 36-55 arasında değişiklik göstermektedir. Bu yarı yapılı görüşmeler, 6 ana araştırma sorusu etrafında şekillenmiştir. Sorular şu şekildedir: (1) Üniversitelerde girişimcilik ve inovasyonun artması için ne tür liderlik modelleri önerirsiniz? (2) Size göre yeni Liderlik yönetiminde neler gereklidir? (3) Özellikle endüstri-üniversite işbirliğinin artması için neler gereklidir? (4) Üniversite yönetiminde böyle bir liderlik modelini adapte edebilmek için en başta nelerin değişmesi gerekmektedir? (5) Endüstriüniversite işbirliğinin etkin olduğu bir yönetimde üniversiteye düşen rol nedir? (6) 
Bu yeni liderlik modelleri üniversiyelerde nasıl uygulanabilir? Yüzyüze yapılan bu görüşmelerde katılımcıların izni alınarak ses kayıt cihazı kullanılmıştır. Yoruma dayalı fenomenolojik analiz ve Atlas.ti 7 ile toplanan veriler analiz edilmiştir.

Çalışmanın analizi sırasında öncelikli olarak tanımlayıcı istatistik verileri elde edildi. Sonrasında tüm görüşmelerin tek tek yazar tarafından deşifresi yazıldı. Yazılı materyaller ses kayıtları ile karşılaştırılarak kontrolleri yapıldı. Her bir katılımcının cevapları vaka bazlı olarak detaylı şekilde incelendi ve içeriğe bağlı farklı kategoriler oluşturuldu. Bir vaka analizi sırasında alınan notlar ve yorumlar değerlendirilerek tek bir katılımcı için tematik bütünlüğe ulaşılana kadar üzerinde tekrar tekrar çalışıldı. Vaka vaka yapılan analizler tamamlandıktan sonra katılımcılar karşılaştırılarak üst kategoriler oluşturuldu ve bir tabloya yerleştirildi. Son olarak da analiz tablosu rapor edilebilir bir format sağlamak amacıyla öyküleyici formata çevirildi.

Araştırmanın Bulguları: Katılımcıların çoğunluğu (percent 78), yenilik ve girişimciliği güçlendirmek için katılımcı demokrasinin yeni liderlik modeli kadar önemli olduğuna değinmiştir. Yeni liderlik yönetiminde çoğunluk (percent 79), yönetimde büyük rol oynayan endüstri üyeleriyle yoğun işbirliğine açılık getirmiştir. Katılımcıların önemli bir oranı (percent 69), üniversitelerin dönüşümlerinde uzmanların dikkate alınması gerektiği konusunda hemfikirdir. Katılımcıların neredeyse yarısına (percent 54) göre üniversiteler, öğrencilerden ve öğretim üyelerinden gelen yeniliği ve yenilikçi düşünceleri daha fazla teşvik edebilir. Bu düşünceyi dile getirenlerin çoğunluğu (percent 87), yeni liderlik ve yönetim tiplerinin, bu değişimi desteklemeye yardımcı olma konusunda son derece önemli olabileceğini söylemiştir.

Katılımcılara liderlik modelleri ile ilgili önerileri sorulduğunda farklı formlarda en sık kullanılan anahtar kelimeler şunlar oldu: 'katılımcı demokrasi', 'katılımcı liderlik' veya 'demokratik liderlik'. İkinci soruda katılımcılara yeni liderlik modeli için nelerin gerekli olduğu sorulduğunda 'yoğun işbirliği' en sık kullanılan anahtar kelimeler oldu. Katılımcılar sıklıkla endüstri-üniversite işbirliğinin çağa ayak uydurma açısından önemini vurgularken pek çoğu bu işbirliğinin üniversite, endüstri ve ekonomi açısından avantajlarını dile getirdi. Bu yeni lirlik modelinin sağlanması için değiştirilmesi gereken ilk şey, katılımcılara göre iletişimin artırılıp fikirlerin daha çok paylaşılması şeklinde oldu. Üniversitelerin içte ve dışta iletişim ağını kuvvetlendirmesi ve düşüncelerin açıklıkla ifade edilmesi hem inovasyon ve girişimciliği desteklemek açısından hem de yönetimle ilgili problem çözümündeki etkisi açısından sıklıkla dile getirildi. Endüstri-üniversite işbirliğinde üniversiteye düşen rol sorulduğunda katılımcıların büyük bir yüzdesi üniversitenin en kısa sürede buna adapte olup dönüşümünü tamamlaması gerektiğini vurguladı. Son olarak bu liderlik modellerinin nasıl uygulanabileceği konusunda en sık kullanılan anahtar kelimelere göre katılımcılar bunun konusunda uzman kişiler vasıtasıyla yapilabileceğini düşünmektedir.

Araştırmanın Sonuçları ve Önerileri: Bu çalışmanın amacı, yeni liderlik türlerini kullanan üniversite yönetimlerinin inovasyon ve girişimciliğe daha açı olup 
olmadıklarını tartışmak olmuştur. Elde edilen bulgulara göre yeni liderlik modellerini uygulayan üniversiteler inovasyona daha uygundur. Geleneksel liderlik modelinin sürdüğü üniversitelerde ise inovasyon ve girişimcilik genellikle desteklenmemektedir. Liderlik konusunda literatürde pek çok çalışma yer alsa da yeni liderlik modellerinin eğitim alanındaki rolünü inceleyen çalışmalar kısıtlıdır. Bu çalışmada ise adapte edilen liderlik modelinin üniversitelerde eğitim, öğretim ve yönetim alanlarındaki etkileri derinlemesine incelenmiştir. Makalenin ayırt edici bir diğer özelliği ise yöntem olarak yoruma dayalı fenomenolojik analizi kullanarak katılımcıların üniversitelerde etkin liderliğin gereklilikleri konusundaki algılarını onların bakış açısından analiz etmesidir.

Literatür ile tutarlı olarak çalışma bulguları üniversite yönetimi liderlik modellerinde katılımcı demokrasinin önemini ortaya çıkarmıştır. Bu demokratik ortamın sağlanması durumunda liderlik gelişimi daha bütünsel bir noktaya ulaşabilir ve üniversiteki etkileyen tüm faktörlerin farkındalığının artmasına yardımcı olabilir. Bir diğer belirgin bulgu ise katılımcıların inovasyon ve girişimcilik alanında motivasyon ve desteğin gerekliliğini vurgulaması şeklindydi. Bu konuda üniversite yönetimine önemli görevler düşmektedir. Organizasyonel kültürü olumlu yönde oluşturma bu anlamda atılacak ilk adım olabilir. Katılımcıların dile getirdiği endüstri üyeleriyle işbiliği konusunun ötesinde liderler üniversitenin içinde ve dışında işbirliği içinde olup stratejik ve işlevsel kararlarda diğerlerinin fikirlerini dinlemelidir. Böylece hem liderler bireysel anlamda hem de üniversiteler organizasyonel anlamda sürekli irtibat halinde kalabilir ve gelişimlerini sürdürebilirler.

Anahtar Sözcükler: Yeni liderlik modeli, üniversite yönetimi, inovasyon, girişimcilik 